\title{
Antioxidant capacity of Melissa Officinalis L. on Biological Systems
}

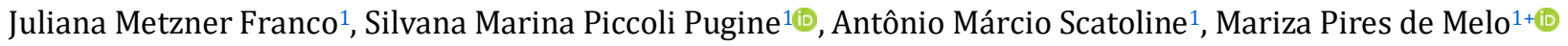 \\ ${ }^{1}$ Faculty of Animal Science and Food Engineering (FZEA), University of São Paulo, Pirassununga, São Paulo, Brazil
}

+ Corresponding author: Mariza Pires de Melo, e-mail address: mpmelo@usp.br

\section{ARTICLE INFO}

Article history:

Received: April 26, 2018

Accepted: September 18, 2018

Published: October 07, 2018

\author{
Keywords: \\ 1. adsorbent \\ 2. textile industry \\ 3. isotherms \\ 4. wastewater
}

ABSTRACT: The aim of the present study was to evaluate in vitro antioxidant capacity of Melissa extract (ME) (Melissa officinalis L.) and its protective effect on peroxyl radical-induced oxidative damage in erythrocytes. ME used in the present study was obtained by rotary evaporation of the crude extract (ethanol:water/dried leaves). Total phenolic and flavonoids determined were $177 \pm 13 \mathrm{mg} \mathrm{GAE} / \mathrm{g}$ dried weight (dw) and $26 \pm 3 \mathrm{mg} \mathrm{QE} / \mathrm{g} \mathrm{dw}$, respectively. Total equivalent antioxidant activities, TEAC in $\mathrm{mg}$ TE/g dw, were $61 \pm 6$ and $512 \pm$ 77 respectively for FRAP assay and $\mathrm{DPPH}^{\circ}$ radical-scavenging. The $\mathrm{ME}$ acts as an antioxidant on $\mathrm{NO}$ and $\mathrm{O}_{2}{ }^{-}$, whereas $\mathrm{ME}$ exerted a higher antioxidant action on NO scavenging compared to the ascorbic acid (1.9 times). However, the antioxidant capacity of $\mathrm{ME}$ on $\mathrm{O}_{2}{ }^{--}$was

5.6 times lower than ascorbic acid. The values of hemolysis inhibition from $\mathrm{ME}\left(\mathrm{IC}_{50}, 2.0 \pm 0.5 \mu \mathrm{g} \mathrm{mL}^{-1}\right)$ were higher than ascorbic acid $\left(\mathrm{IC}_{50}, 7 \pm 2 \mu \mathrm{g} \mathrm{mL}^{-1}\right)$. Extract of Melissa was able to eliminate biological free radicals, suggesting a potential to prevent oxidative damage in vivo. In fact, the ME exerted protective action on cell membrane lysis in situ.

\section{Introduction}

Melissa officinalis L. (lemon balm) is a plant of the Laminacea family originated from the Mediterranean, East Asia, Southeast Siberia and North Africa but has adapted throughout the world ${ }^{1}$. Studies show the benefits of M. officinalis as antioxidant ${ }^{2-4}$ which were used for the symptomatic treatment of gastrointestinal disturbances, adjuvant therapy for pain associated to functional dyspepsia, neurological diseases associated with oxidative stress ${ }^{5}$. The rosmarinic acid is the major compound present in the ethanol extract of $M$. officinalis ${ }^{3,6,7}$. Some properties of $M$. officinalis are related to the high levels of polyphenolic compounds as quercetin, caffeic acid and rosmarinic acid with antioxidant properties ${ }^{3,8}$.

Antioxidants are compounds with protective action on deleterious effect of reactive species such

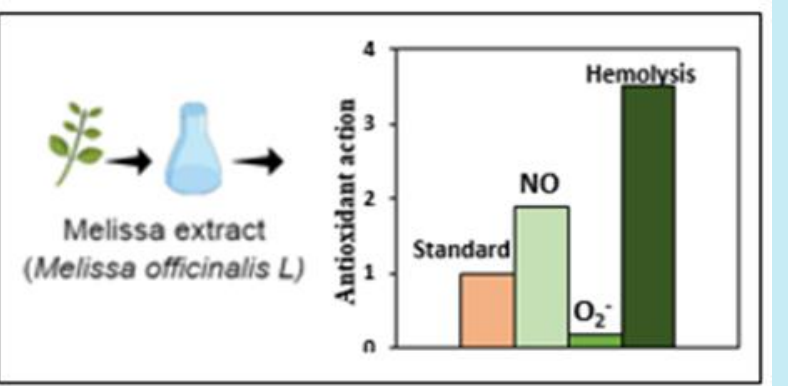

as reactive oxygen species (ROS) and reactive nitrogen species (RNS) ${ }^{9}$. Reactive species are atoms or molecules that have high oxidizing power and can be a radical with unpaired electron as superoxide anion $\left(\mathrm{O}_{2}{ }^{*}\right)$, hydroxyl radical $\left(\mathrm{HO}^{\circ}\right)$ and nitric oxide ( $\mathrm{NO}^{\circ}$ or $\mathrm{NO}$ ) or non-radicalar forms as hydrogen peroxide $\left(\mathrm{H}_{2} \mathrm{O}_{2}\right)$ or peroxynitrite anion $\left(\mathrm{ONOO}^{-}\right)^{9,10}$. ROS can be formed in the cellular environment primarily as result of aerobic metabolism. Nitric oxide, a natural free radical, whose generation is related to normal physiological parameters; but when combined with ROS has potent pro oxidant effects ${ }^{11}$.

Exacerbated reactive species in the cellular medium can be due to an unbalanced diet and xenobiotics exposure ${ }^{12}$. For food processing the oxygen level, the presence of transition metals and high temperatures are important to the reactive species generation ${ }^{11,12}$. Macromolecules oxidation 
by reactive species can cause serious problems in biological systems by ultracellular damage or in food industry by off flavor, changes in nutritional properties and shelf life; so, the use of antioxidants is an important mechanism against reactive species. In recent years the interest for natural antioxidant has intensified for food manufactures and both human and animal diet ${ }^{13,14}$. Different species of herbs have been investigated by the chemical composition, antioxidant activity and antimicrobial action, among them $M$. officinalis.

Antioxidant activity can be evaluated by radical scavenging using non-biological radicals such as DPPH $^{\circ}$ (2,2-diphenyl-1-picrylhydrazyl) and ABTS $^{\circ+} \quad$ (2,2'-azino-bis-3-ethylbenzthiazoline $)^{15}$. However, recently, radicals with biological characteristics as $\mathrm{O}_{2}{ }^{-}$and $\mathrm{NO}$ have been employed to evaluate antioxidant activity ${ }^{16}$. Thermal decomposition of AAPH (2,2'-azobis-2amidinopropane dihydrochloride) in vitro generates peroxyl radical that has been used to verify the antioxidant activity against oxidative erythrocytes damage induced by this radical ${ }^{17}$. Reactive species such as peroxyl radical and others as $\mathrm{O}_{2}{ }^{-}$and $\mathrm{NO}$ are important for antioxidant assays by simulating a biological process.

The aim of this study was to evaluate the antioxidant activity of extract of Melissa officinalis L. on biological systems. For this purpose the aqueous $M$. officinalis extract obtained by ethanol:water (70:30) extraction was used to determinate: $i$ ) total phenolic by Folin-Ciocalteau method and total flavonoids by aluminum chloride reaction; ii) antioxidant activity on non-biological species as ferric ion reducing (FRAP assay) and $\mathrm{DPPH}^{*}$ scavenging; iii) antioxidant activity on free radical with biological characteristics, $\mathrm{O}_{2}{ }^{--}$and $\mathrm{NO}$ scavenging and $i v$ ) antioxidant activity on hemolytic AAPH-induced.

\section{Materials and methods}

\subsection{Plant and chemicals}

Dried leaves of $M$. officinalis were acquired from Florien (Piracicaba, São Paulo, Brazil). All chemicals compounds were obtained from SigmaAldrich (St. Louis, EUA).

\subsection{Obtainment of Extract}

Dried leaves of Melissa officinalis were micronized using a micro mill Willye (TE-648, Tecnal) and stored in amber vial. Micronized sample (10 g) was subjected to lipids removal using n-hexane $(300 \mathrm{~mL})$ on Soxhlet extractor for $6 \mathrm{~h}^{18}$. Subsequently, the bioactive compounds from each sample was extracted with ethanol:water (70:30, $\mathrm{v}: \mathrm{v})$ by stirring (170 rpm) (Shaker TE-420, Tecnal), at $25{ }^{\circ} \mathrm{C}$ for $24 \mathrm{~h}$, in the dark. After extraction, the solution was centrifuged for $10 \mathrm{~min}$ at $4000 \mathrm{rpm}$ (Centrifuge CT-500, Cientec), filtered Whatman no.1 $(11 \mu \mathrm{M})$ and the solvent was evaporated under reduced pressure with the temperature not exceeding $50{ }^{\circ} \mathrm{C}$ (rotary evaporator SL-126, Solab). The concentrated extract was diluted in ultrapure water, sonicated 3 times for 20 $\mathrm{s}$ at $90 \mathrm{~Hz}$ (ultrasonic cell disrupter, UNIQUE) and centrifuged at $4000 \mathrm{rpm}$ for $5 \mathrm{~min}$. The supernatant was frozen and freeze-dried (Lyophilizer K-202, Liobras) and finally, the sample was resuspended in ultrapure water and used in all assays. To assay with cells the final extract concentration was adjusted to $10 \mathrm{mM}$ phosphate buffer saline, $\mathrm{pH} 7.4$, (PBS). Dry weight (dw) of aqueous extract was evaluated for results expression. The procedure described above was performed in triplicate $(n=3)$.

\subsection{Estimation of total phenolic and total flavonoids}

Total phenolics were estimated using FolinCiocalteau reagent ${ }^{19}$. In this technique, the extract was pre-incubated with $10 \%$ (v/v) Folin-Ciocalteu reagent for $2 \mathrm{~min}$ and $7.5 \%(\mathrm{w} / \mathrm{v})$ sodium carbonate was added. After $1 \mathrm{~h}$ at $25^{\circ} \mathrm{C}$, absorbance at 760 $\mathrm{nm}$ was measured in a spectrophotometer (DU800, Beckman Coulter ${ }^{\circledR}$ ). Assays were performed in triplicate and results were expressed as $\mathrm{mg}$ of gallic acid equivalents (GAE)/g dw, using a standard curve of gallic acid $\left(0.5\right.$ to $\left.6.0 \mu \mathrm{g} \mathrm{mL}^{-1}\right)$.

Total flavonoids were carried in accordance with the colorimetric method ${ }^{20}$. Assay was performed in ethanol:water 70:30 (v:v) in the presence of $2 \%(\mathrm{w} / \mathrm{v})$ aluminum chloride and extract. Absorbance at $415 \mathrm{~nm}$ was determinate, after $40 \mathrm{~min}$ of incubation at $25{ }^{\circ} \mathrm{C}$ in the dark, using a spectrophotometer (DU-800, Beckman Coulter ${ }^{\circledR}$ ). Assays were performed in triplicate and results were expressed in $\mathrm{mg}$ of quercetin equivalent $(\mathrm{QE}) / \mathrm{dw}$, using a standard curve of quercetin $\left(0.6\right.$ to $\left.9.6 \mu \mathrm{g} \mathrm{mL}^{-1}\right)$.

\subsection{Ferric reducing antioxidant power (FRAP) assay}

The reduction power of extract on ferric ion was described previously ${ }^{21}$. The reaction between extract and FRAP reagent produces a blue compound and absorbance was measured at 593 
nm (DU-800, Beckman Coulter ${ }^{\circledR}$ ). FRAP reagent was prepared by mixing acetate buffer $(300 \mathrm{mM}$, $\mathrm{pH}$ 3.6), $10 \mathrm{mM}$ tripiridiltriazine in $40 \mathrm{mM} \mathrm{HCl}$, and $20 \mathrm{mM} \mathrm{FeCl}_{3}$ at ratio 10:1:1 (v:v:v). A standard curve was prepared with Trolox (0.63 to $3.78 \mu \mathrm{g}$ $\left.\mathrm{mL}^{-1}\right)$. Assays were performed in triplicate and results were expressed as $\mathrm{mg}$ trolox equivalente (TE)/g dw.

\subsection{Radical DPPH' scavenging}

Antioxidant activity of extract on $\mathrm{DPPH}^{\circ}$ radical (2,2-diphenyl-1-picryl-hidrazil) was described above $^{22}$. A methanol solution of DPPH $(65 \mathrm{mM})$ and extract at different concentrations (2.5 to 16.5 $\mathrm{mg} \mathrm{mL}^{-1}$ ) were used to determine the $\mathrm{EC}_{50}$ (concentration required to reduce $50 \%$ of $\mathrm{DPPH}^{\circ}$ inhibition). A control assay was performed in the absence of extract to obtain the initial absorbance at zero time. After $3 \mathrm{~h}$ of incubation at $25{ }^{\circ} \mathrm{C}$, the absorbance at $515 \mathrm{~nm}$ was determined (DU-800, Beckman Coulter $^{\circledR}$ ). The antioxidant activity was assessed by reduction of absorbance value from $\mathrm{DPPH}^{\circ}$ compared to the initial absorbance from control assay. The results were expressed as inhibition percentage of $\mathrm{DPPH}^{\circ}$ in Equation 1. Assays were performed in triplicate and results were expressed as mean \pm standard deviation $\mathrm{mg}$ $\mathrm{TE} / \mathrm{g} \mathrm{dw}$, calculated from a standard Trolox curve with concentrations 0.32 to $6.3 \mathrm{mg} \mathrm{mL}{ }^{-1}$. $\mathrm{EC}_{50}$ values were expressed in $\mathrm{mg} \mathrm{mL}^{-1}$ of extract.

$$
\text { DPPH'inhibition }(\%)=\left[1-\left(A_{A} / A_{C 0}\right)\right] \times 100
$$

where: $A_{C 0}=$ absorbance at $515 \mathrm{~nm}$ from control assay at initial time; $\mathrm{A}_{\mathrm{A}}=$ absorbance at $515 \mathrm{~nm}$ from assay in the presence of extract after $3 \mathrm{~h}$ of incubation.

\subsection{Superoxide anion $\left(\mathrm{O}_{2}{ }^{-}\right)$and nitric oxide (NO) scavenging}

The antioxidant activity on $\mathrm{O}_{2}{ }^{--}$was determined according to the methodology proposed previously $^{8,23,24}$. The assay used NADH $(166 \mu \mathrm{M})$, NBT $(43 \mu \mathrm{M})$, PMS $(2.7 \mu \mathrm{M})$ and extract at different concentrations (20 to $600 \mu \mathrm{g} \mathrm{mL}^{-1}$ ). All reagents were prepared in PBS. After incubation for $2 \mathrm{~min}$ at $25^{\circ} \mathrm{C}$, the absorbance was determined at $540 \mathrm{~nm}$ on microplate reader (Thermo Scientific Uniscience ${ }^{\circledR}$ ). A control assay (without extract) was performed under the same conditions. Inhibition percentage of $\mathrm{O}_{2}{ }^{-}$is described in Equation 2. Assays were performed in triplicate and results were expressed as mean \pm standard deviation as inhibition percentage compared to control assay. Ascorbic acid, as standard antioxidant was used in similar conditions.

$O_{2}^{\cdot-}$ inhibition $(\%)=\left[1-\left(A_{A} / A_{C 0}\right)\right] \times 100$

where: $A_{C 0}=$ absorbance at $540 \mathrm{~nm}$ from control assay; $A_{A}=$ absorbance at $540 \mathrm{~nm}$ from assay in the presence of extract.

For nitric oxide (NO) assay was used the proposed method ${ }^{25}$, with modifications ${ }^{8,26}$. Assay performed in PBS containing $10 \mathrm{mM}$ sodium nitroprusside and extract $\left(2.5\right.$ to $\left.100 \mu \mathrm{g} \mathrm{mL}^{-1}\right)$ were incubated at $25{ }^{\circ} \mathrm{C}$ for $3 \mathrm{~h}$. Control assay (without extract) was performed under the same conditions, when $100 \%$ nitrite formation was observed. Each 1 $\mathrm{h}$, aliquot from each assay was transferred to 96well plate containing sulfanilamide $(1 \%$, w/v). After $5 \mathrm{~min}, \mathrm{~N}-(1-\mathrm{Naphthyl})$ ethylenediamine dihydrochloride $(0.1 \%$, w/v) has been added, incubated for $5 \mathrm{~min}$ and absorbance at $540 \mathrm{~nm}$ evaluated using a microplate reader (Thermo Scientific Uniscience ${ }^{\circledR}$ ). The concentration of sodium nitrite $\left(\mu \mathrm{mol} \mathrm{L^{-1 }}\right)$ in the assays was calculated from a standard curve of sodium nitrite (1.56 to $100 \mu \mathrm{mol} \mathrm{L}^{-1}$ ). The $\mathrm{NO}$ inhibition percentage by the extract was determined after $2 \mathrm{~h}$ of incubation and was calculated relative to the control assay (Equation 3). Assays were performed in triplicate and results were expressed as mean \pm standard deviation. Ascorbic acid, as standard antioxidant was used in similar conditions.

$$
\text { Inhibition } N O(\%)=\left[1-\left(A_{A} / A_{C 0}\right)\right] \times 100
$$

where: $A_{\mathrm{C} 0}=$ absorbance at $540 \mathrm{~nm}$ from control assay; $\mathrm{A}_{\mathrm{A}}=$ absorbance at $540 \mathrm{~nm}$ from assay in the presence of extract.

\subsection{Protective effect on hemolytic AAPH-induced in human erythrocytes}

To evaluate the extract action on hemolysis induced by AAPH was employed the method described above ${ }^{8,27,28}$. Human erythrocytes, from venous blood, were obtained from healthy and nonsmokers people using vacutainer tubes containing ethylenediamine tetraacetic acid (EDTA). The cell suspension was prepared according to Gião et al. ${ }^{17}$ and this suspension was kept at $4{ }^{\circ} \mathrm{C}$ and used within $4 \mathrm{~h}$. The volunteers 
signed consent and informed, previously approved by the Local Committee of Ethics in Human Research (number: 493.382).

The erythrocytes suspensions (1\%) were incubated for $30 \mathrm{~min}$ in the absence (control assay) as well in the presence of the extract $(0.25$ to $15 \mathrm{mg}$ $\mathrm{mL}^{-1}$ ) at $37{ }^{\circ} \mathrm{C}$ under agitation at $100 \mathrm{rpm}$ (shaker TE - 420 Tecnal $^{\circledR}$ ). So, each assay received $5 \mathrm{mmol}$ $\mathrm{L}^{-1}$. AAPH and the incubation proceeded for $6 \mathrm{~h}$. Simultaneous, assays in the absence of AAPH were performed, under same conditions, to evaluate spontaneous hemolysis; the effect of extract alone on cell lyses was also tested. The complete hemolysis $(100 \%)$ was established by incubating erythrocytes $(1 \%)$ in water at $37{ }^{\circ} \mathrm{C}$ for $10 \mathrm{~min}$. Hemolysis was measured, at each $1 \mathrm{~h}$, by hemoglobin absorbance in the extracellular medium at $540 \mathrm{~nm}$ using a microplate reader (Thermo Scientific Uniscience ${ }^{\circledR}$ ). Assays were performed in duplicate and the results expressed as percentage of hemolysis according to Equation 4. The percentage of hemolysis inhibition related to the control assay was obtained according to Equation 5. Ascorbic acid, as standard antioxidant was used in similar conditions.

Hemolysis $(\%)=\left(A_{A} / A_{100 \%}\right) \times 100$

Hemolysisinhibition $(\%)=\left[1-\left(A_{A} / A_{C}\right)\right] \times 100$

where: $\mathrm{A}_{\mathrm{A}}=$ absorbance at $540 \mathrm{~nm}$ from assay in the presence of extract; $\mathrm{A}_{100 \%}=$ absorbance at 540 $\mathrm{nm}$ from complete hemolytic assay $(100 \%) ; \mathrm{A}_{\mathrm{C}}=$ absorbance at $540 \mathrm{~nm}$ from control assay.

\subsection{Statistic analysis}

The data were evaluated by analysis of variance (ANOVA), t-test and Tukey's test for comparison of means, with a significance level of 5\%, using Minitab ${ }^{\circledR}$ software 16.2.2 (2010 Minitab Inc.).

\section{Results and discussion}

3.1 Total phenolic and flavonoid contents and antioxidant activity against ferric reducing power $(F R A P)$ and free radical scavenging $\left(\mathrm{DPPH}^{\circ}, \mathrm{NO}\right.$ and $\mathrm{O}_{2}{ }^{\circ}$ )

The present study determined the antioxidant properties of $M$. officinalis and its action on reactive species. Total phenolic and flavonoids content on ME, evaluated by spectrophotometry, were $177 \pm 13 \mathrm{mg} \mathrm{GAE} / \mathrm{g} \mathrm{dw}$ and $26 \pm 3 \mathrm{mg} \mathrm{QE} / \mathrm{g}$ dw, respectively. Results expressed by mean and standard deviation $(\mathrm{n}=3)$. Lamiaceae family, including the $M$. officinalis species, has been studied for polyphenolic presence and total antioxidant properties ${ }^{2}$. Results from FolinCiocalteau assays reflect the reducing power of the sample, including total polyphenols and other compounds such as: aromatic amines; ascorbic acid; sugars; organic acids and some inorganic compounds $^{12}$. However, Folin-Ciocalteau method has been used to estimate total phenolic compounds. Folin-Ciocalteau values, in the present study, were similar the ethanolic (98\%) $M$. officinalis extract $(175 \pm 11 \mathrm{mg}$ GAE/g of dry extract) and slightly higher for the content of flavonoid (54 $\pm 4 \mathrm{mg}$ catechin equivalent/g of dried extract $)^{4}$. However, lower values using ethanolic (80\%) M. officinalis extract by Folin-Ciocalteau assay (13.2 mg GAE/100 g dw) were found ${ }^{6}$. Another study showed the total polyphenols around 69.49-76.43 mg GAE/g dry plant and total flavonoids 7.0-10.0 mg QE/g dry plant from ethanolic (70\%) M. officinalis extract, dependent of the harvesting period and hour ${ }^{7}$.

Fernandes et al. ${ }^{2}$ evaluated six families of aromatic herbs and the Lamiaceae family showed higher values of total phenolic by Folin-Ciocalteau assay, compared to other families. These authors found $42.86 \mathrm{mg} \mathrm{GAE} / \mathrm{g} \mathrm{dw}$ for ME using acetone:water:acetic acid (70:28:2) as extractor solvent. So, aqueous extracts of $M$. officinalis prepared by decoction were $1245 \mathrm{mg} \mathrm{GAE} / \mathrm{g} \mathrm{dw}$ and by infusion mode were $267 \mathrm{mg} \mathrm{GAE} / \mathrm{g} \mathrm{dw}^{3}$. Rababah et al. (2015) ${ }^{29}$ studying methanolic extract from leaves of $M$. officinalis found $303.2 \mathrm{mg}$ GAE/100 g fresh plant and $252.9 \mathrm{mg}$ of cathequin equivalent/100 $\mathrm{g}$ fresh plant. Thus, several factors may affect the absolute values of total phenolics and flavonoids contents, including genotype, growing conditions, parts tested, time of taking sample and extraction methods. Recently, the content of total flavonoids by spectrophotometric method was evaluated in different plants extracts and M. officinalis specie showed high flavonoids content ${ }^{30}$.

In the present study, the obtained total antioxidant activity of ME measured by FRAP assay was $61 \pm 6 \mathrm{mg} \mathrm{TE} / \mathrm{g} \mathrm{dw}$, result expressed by mean and standard deviation $(\mathrm{n}=3)$. A proportional decrease in the absorbance versus the sample concentration was observed (data not show). For $\mathrm{DPPH}^{*}$ radical scavenging, $3 \mathrm{~h}$ were necessary to reach an absorbance plateau, thus ensured that the 
derivative zero of the absorbance by time (Figure 1A). Non-linear decay behavior of the absorbance versus time using some extract concentrations was observed, the stability achieved after $3 \mathrm{~h}$ of reaction. Dose-response on DPPH radical scavenging by extract after $3 \mathrm{~h}$ of reaction was studied (Figure 1B). High linear correlation coefficient $\left(r^{2}=0.9935\right)$ was found for $\mathrm{DPPH}^{\circ}$ scavenging and extract concentration $(0.5-17.0 \mu \mathrm{g}$ $\mathrm{mL}^{-1}$ ). Similar behavior was presented by Trolox, a standard antioxidant, at concentration of 1.0-6.0 $\mu \mathrm{g}$ $\mathrm{mL}^{-1}\left(\mathrm{r}^{2}=0.9826\right)$ (Figure $\left.1 \mathrm{~B}\right) . \mathrm{IC}_{50}$ values were 9 $\pm 1 \mu \mathrm{g} \mathrm{mL}^{-1}$ and $5.5 \pm 0.2 \mu \mathrm{g} \mathrm{mL}^{-1}$ to extract and Trolox, respectively. These results suggest that the ME has antioxidant activity on non-biological radical DPPH', but slightly less efficient than Trolox. Total antioxidant activity of ME measured by $\mathrm{DPPH}^{*}$ scavenging was $512 \pm 77 \mathrm{mg} \mathrm{TE} / \mathrm{g} \mathrm{dw}$, as mean and standard deviation.
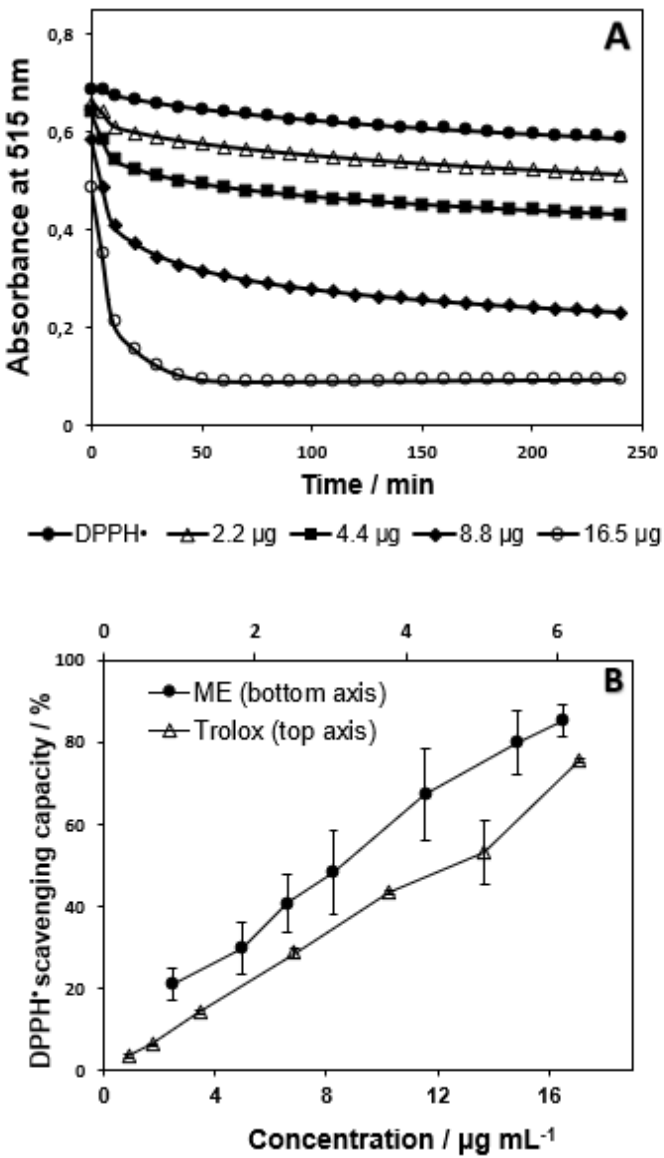

Figure 1. Antioxidant activity of ME on $\mathrm{DPPH}^{*}$ scavenging. (A) Absorbance versus reaction time in absence of extract (only DPPH') and presence of extract $(2.2,4.4,8.8,15.5 \mu \mathrm{g})$. (B) $\mathrm{DPPH}^{*}$ scavenging by $\mathrm{ME}$ $\left(0.5\right.$ at $\left.17.0 \mu \mathrm{g} \mathrm{mL}^{-1}\right)$ and by Trolox (1.0 at $6.0 \mu \mathrm{g} \mathrm{mL}^{-}$ $\left.{ }^{1}\right)$, after $3 \mathrm{~h}$ of incubation mean \pm standard deviation for assay made in triplicate from 3 extractions $(n=3)$.
FRAP assay is based on the ability of different antioxidants, including phenolics, to reduce $\mathrm{Fe}^{3+}$ to $\mathrm{Fe}^{2+}$ in the presence of FRAP-reagent, forming a blue chromophore. Results obtained here indicating that ME had effective reducing power and showed similar characteristic when compared to the standard ascorbic acid. Total antioxidant activity of ME measured by FRAP assay was $61 \pm$ $6 \mathrm{TE} / \mathrm{g} \mathrm{dw}$, in the present study, contrasting with the results found in previous study using another extractor solvent $(464.8 \mu \mathrm{mol} \mathrm{TE} / \mathrm{g}$ dw that correspond $117 \mathrm{mg} \mathrm{TE} / \mathrm{g} \mathrm{dw})^{2}$. In the present study, FRAP assay corroborates the Folin-Ciocalteau values and can indicate high reducing power of the sample, suggesting great antioxidant potential from the ME. Reducing power can be associated with antioxidant activity of plant extract ${ }^{31}$. The reduction power indicates that the antioxidant compounds present in the sample are electron donors and can react with free radicals to stabilize and block chain reactions ${ }^{1}$.

Antioxidant compounds can act on free radicals by scavenging mechanisms, which may be attributed to its hydrogen and/or electron donating; thus, they might prevent reactive radical species from reaching biomolecules such as lipoproteins, polyunsaturated fatty acids, DNA, amino acids, proteins and food systems ${ }^{32}$. It is well described that $\mathrm{DPPH}^{\bullet}$ radical is a good model for assessing antioxidant activity ${ }^{22}$. Here, M. officinalis showed a concentration-dependent $\mathrm{DPPH}^{\circ}$ radical scavenging. The $\mathrm{DPPH}^{*}$ radical assay is based on the reduction of $\mathrm{DPPH}^{*}$ radical to a non-radical compound by antioxidant agents, e.g. M. officinalis extract. In the present study, the extract showed a potent action on the DPPH ${ }^{*}$ scavenging which $\mathrm{IC}_{50}$ is similar to other studies of aqueous and methanol extract of $M$. officinalis $\left(18.74 \mu \mathrm{g} \mathrm{mL}^{-1}\right.$ and 13.74 $\mu \mathrm{g} \mathrm{mL} L^{-1}$, respectively $)^{33}$.

Studies with aqueous $\mathrm{ME}$ exhibited $\mathrm{IC}_{50}$ to $\mathrm{DPPH}^{\circ}$ scavenging from $1.53-1.62 \mu \mathrm{g} \mathrm{mL} \mathrm{mL}^{-1}$. Results presented here show values $10 \times$ higher than antioxidant activity of ME against $\mathrm{DPPH}^{\circ}$ radical scavenging found previously $(5.57 \mathrm{~g}$ $\mathrm{TE} / 100 \mathrm{~g} \mathrm{dw}$, that correspond $55.7 \mathrm{mg} \mathrm{TE} / \mathrm{g} \mathrm{dw})^{2}$. There is a large variation in the absolute values for the $\mathrm{DPPH}^{-}$radical scavenging by ME. However, this found suggests that the ME can eliminate free radicals at physiological $\mathrm{pH}$ and can be of beneficial interest in preservation of biological systems, where free radical mediates some reactions including lipid oxidation. $\mathrm{DPPH}^{*}$ radicalscavenging from ME ethanolic $(80 \%)$ shows $\mathrm{IC}_{50}$ 
equal $48.76 \mu \mathrm{g} \mathrm{mL}^{-1}$, which is less efficient than ascorbic acid $\left(6.64 \mu \mathrm{g} \mathrm{mL}^{-1}\right)^{34}$. Antioxidant activity of ME on DPPH' radical scavenging was 3.03-6.34 $\mu \mathrm{mol}$ Trolox $/ \mathrm{mL}$ of water extract, depending on the extraction procedure as temperature and ultrasound bath $^{35}$.

To nitric oxide assay, the antioxidant activity of extract was measured by decrease of nitrite $\left(\mathrm{NO}_{2}{ }^{-}\right)$ concentration over reaction time (Figure 2A). Melissa extract activity on NO radical scavenging was estimated by the decreasing of $\mathrm{NO}_{2}^{-}$ concentration. After $3 \mathrm{~h}$ of reaction, NO inhibition by extract in different concentrations $(0.5-100 \mu \mathrm{g}$
$\mathrm{mL}^{-1}$ ) was studied (Figure 2B). However, a good linear correlation coefficient $\left(r^{2}=0.9895\right)$ was found for $\mathrm{NO}$ radical scavenging and extract concentration $\quad\left(0.5-17.0 \quad \mu \mathrm{g} \quad \mathrm{mL}^{-1}\right)$. Similar characteristic was found by ascorbic acid evaluated in a concentration range of $0.5-200 \mu \mathrm{g} \mathrm{mL}^{-1}$ (Figure 2B); and good linear correlation coefficient $\left(\mathrm{r}^{2}=\right.$ 0.9901 ) between this radical scavenging and ascorbic acid concentration $\left(0.5-25 \mu \mathrm{g} \mathrm{mL}{ }^{-1}\right)$ was observed. So, $\mathrm{IC}_{50}$ value for the ME $(35 \pm 12 \mu \mathrm{g}$ $\left.\mathrm{mL}^{-1}\right)$ was better than ascorbic acid $(68 \pm$ $\left.17 \mu \mathrm{g} \mathrm{mL}^{-1}\right)$.
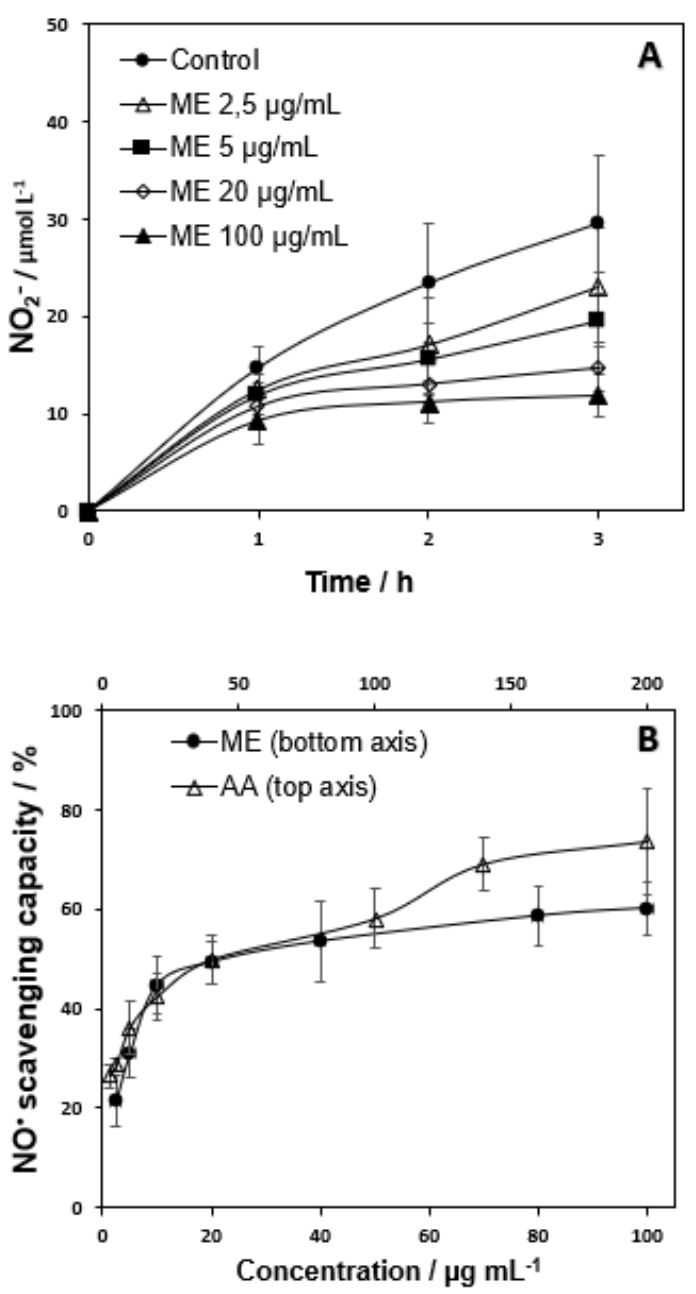

Figure 2. Antioxidant activity of $\mathrm{ME}$ on $\mathrm{NO}$ scavenging. (A) $\mathrm{NO}_{2}{ }^{-}$concentration versus reaction time in the absence of extract (control) and the presence of extract $\left(2.5\right.$ at $\left.100 \mu \mathrm{g} \mathrm{mL}^{-1}\right)$. (B) NO scavenging by ME $\left(2.5\right.$ at $\left.100 \mu \mathrm{g} \mathrm{mL}^{-1}\right)$ and by ascorbic acid (AA, 2.5 at $200 \mu \mathrm{g} \mathrm{mL}^{-1}$ ), after $3 \mathrm{~h}$ of incubation. Mean \pm standard deviation for assay made in triplicate from 3 extractions $(n=3)$.

The NO radical-scavenging by antioxidants is performed by the quantification of nitrite ions $\left(\mathrm{NO}_{2}{ }^{-}\right)$generated by reaction between $\mathrm{NO}$ and molecular oxygen ${ }^{25}$. However, the antioxidant action of ME on NO can be deduced by the low concentration of $\mathrm{NO}_{2}{ }^{-}$. Other studies show that plant extracts were effective for NO scavenging, when $\mathrm{IC}_{50}$ values from 18 different plant species on NO inhibition were 51-604 $\mu \mathrm{g} \mathrm{mL}^{-1}{ }^{10}$. So, $\mathrm{IC}_{50}$ for the ME was $35 \pm 12 \mu \mathrm{g} / \mathrm{mL}$ in present study. 
Normally, the reaction mechanism to NO radical scavenging by plants extracts involves phenolic compounds ${ }^{36}$. ME has shown various phenolic compounds such as rosmarinic acid and others $^{10}$, in fact, these compounds can be related to the NO radical scavenging. The NO is a natural compound produced in vivo by variety of cells and is an important bio-regulatory molecule with several physiological functions ${ }^{11,37}$. However, under oxidative stress this reactive species combines with other reactive species to produce more toxic effects ${ }^{11}$. Therefore, the scavenging effect of ME was assessed against this radical. NO radical scavenging by extract has an interest in human health. It is well known that NO plays an important role in the prevention of various pathologies such as atherosclerosis, ischemia reperfusion, neurodegenerative diseases such as Alzheimer's and Parkinson's disease, cancer and diabetes ${ }^{11,37-39}$.

A relationship between the concentration of $\mathrm{ME}$ and $\mathrm{O}_{2}{ }^{-}$inhibition was obtained in $0.5-600 \mu \mathrm{g} \mathrm{mL}$ ${ }^{1}$ range to extract and $0.5-200 \mu \mathrm{g} \mathrm{mL}^{-1}$ to ascorbic acid (Figure 3). However, linear correlation between $\mathrm{O}_{2}{ }^{-}$scavenging and $\mathrm{ME}$ extract at $0.5-80$ $\mu \mathrm{g} \mathrm{mL} \mathrm{mL}^{-1}\left(\mathrm{r}^{2}=0.9781\right)$ was obtained; and for ascorbic acid in the range $0.5-25 \mu \mathrm{g} \mathrm{mL} L^{-1}\left(\mathrm{r}^{2}=\right.$ 0.9879). Therefore, the effect of extract on $\mathrm{O}_{2}{ }^{*}$ scavenging was $5.6 \times$ lower than for ascorbic acid, observed, respectively, by IC $_{50}$ values, $247 \pm 43 \mu \mathrm{g}$ $\mathrm{mL}^{-1}$ and $44 \pm 18 \mu \mathrm{g} \mathrm{mL}^{-1}$.

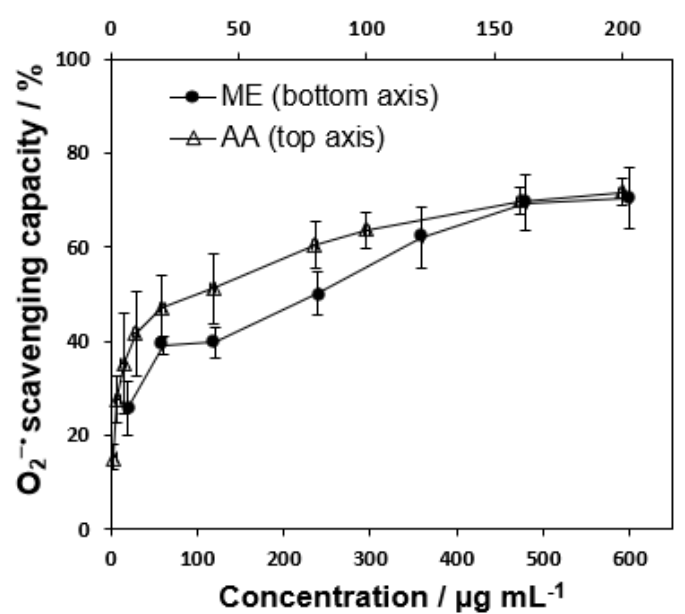

Figure 3. Antioxidant activity on $\mathrm{O}_{2}{ }^{*-}$ scavenging by ME (20 at $600 \mu \mathrm{g} \mathrm{mL}^{-1}$ ) and by ascorbic acid (AA, 10 at $\left.200 \mu \mathrm{g} \mathrm{mL}^{-1}\right)$. Mean \pm standard deviation for assay made in triplicate from 3 extractions $(n=3)$.

The $\mathrm{O}_{2}{ }^{-}$radical scavenging determination is based on the formazan chromophore formation by reaction between this radical and nitro blue tetrazolium, at physiological $\mathrm{pH}$; antioxidant compound reacts with $\mathrm{O}_{2}{ }^{-*}$ and chromophore formation is inhibited ${ }^{24}$. In the present study, the $\mathrm{O}_{2}{ }^{\circ-}$ radical scavenging by $\mathrm{ME}$ was $5.6 \times$ lower than ascorbic acid. Other authors showed $\mathrm{IC}_{50}$ variation from 44 to $386 \mu \mathrm{g} \mathrm{mL}^{-1}$ for $\mathrm{O}_{2}{ }^{-}$scavenging in aqueous ME from several cultivars ${ }^{30}$; our results are within the reported range $\left(247 \pm 43 \mu \mathrm{g} \mathrm{mL}^{-1}\right)$.

Recent studies reported that $\mathrm{O}_{2}{ }^{-}$radical scavenging by plant aqueous extracts can be due to the presence of hydroxyl groups in phenolic compounds ${ }^{38}$. The $\mathrm{O}_{2}{ }^{-}$is an important reactive oxygen species in vivo and can generate highly toxic species through reactions with other reactive species or by enzymatic reactions or metal catalyzed processes. The $\mathrm{O}_{2}{ }^{-}$mediated oxidative stress and it is believed to be involved in pathogenesis disorders such as diabetes mellitus, Alzheimer's and Parkinson's diseases ${ }^{39}$.

\subsection{Anti-hemolytic action on AAPH-induced lysis}

Results from action of ME on hemolysis inhibition are shown in Figure 4. The hemolysis percentage induced by AAPH has a sigmoidal characteristic over time (Figure 4A). When low hemolysis percentages up to $2 \mathrm{~h}$ and after $5 \mathrm{~h}$ of incubation $30 \%$ hemolysis was seen, compared to $100 \%$ hemolysis induced by water. However, MEs at $1-10 \mu \mathrm{g} \mathrm{mL}^{-1}$ were antihemolytic on AAPHinduced lysis following a dose-dependent characteristic. No hemolysis by the extract $(10 \mu \mathrm{g}$ $\mathrm{mL}^{-1}$ ) alone, in the absence of AAPH, was detected. Figure 4B shows dose-dependence of antioxidant concentration and inhibition hemolysis percentage after $4 \mathrm{~h}$ of erythrocytes incubation in the presence of extract or ascorbic acid in a concentration range from 0.5 to $15 \mu \mathrm{g} \mathrm{mL}^{-1}$. Linear correlation between hemolysis inhibition and antioxidant concentration $\left(0.5-8 \mu \mathrm{g} \mathrm{mL}^{-1}\right)$ showed $\mathrm{r}^{2}=0.9987$ and $\mathrm{r}^{2}=0.7899$ for Melissa extract and ascorbic acid, respectively. $\mathrm{IC}_{50}$ values indicated that the extract was more efficient in protecting red blood cell lysis, since $\mathrm{IC}_{50}$ for extract was $2.0 \pm 0.5 \mu \mathrm{g} \mathrm{mL}^{-1}$ and for ascorbic acid $7 \pm 2 \mu \mathrm{g} \mathrm{mL}^{-1}$. 

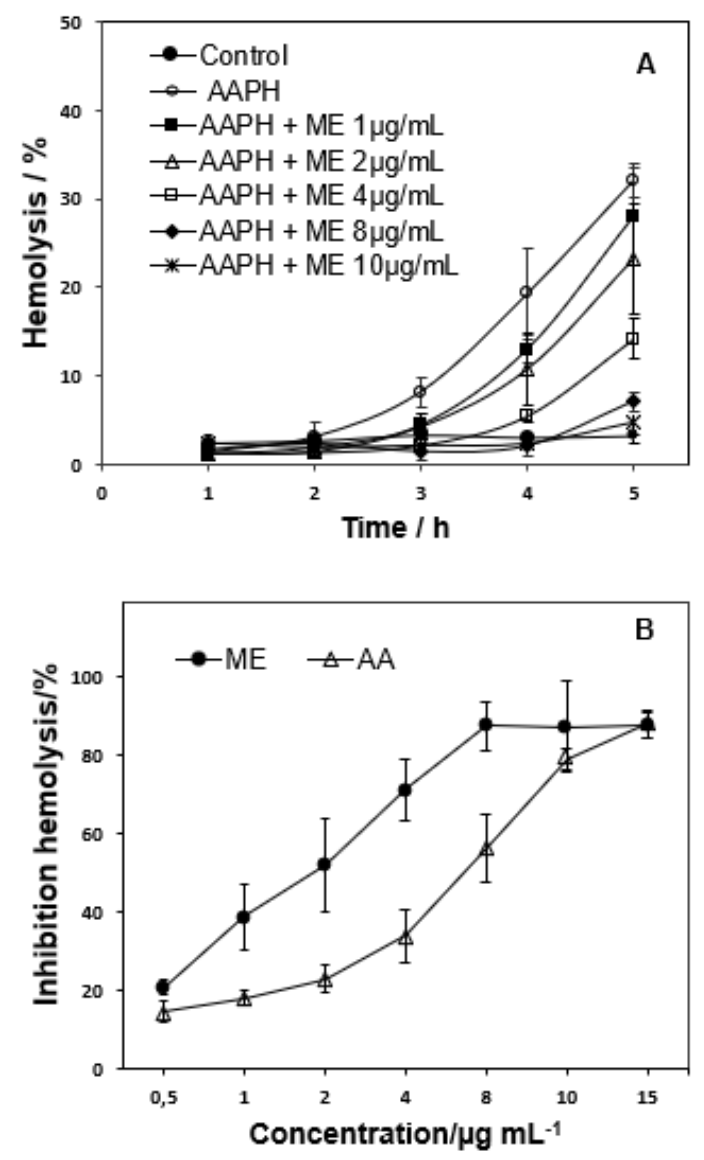

Figure 4. Antihemolytic action of ME. (A) Percentage of AAPH-induced hemolysis over time evaluated in absence and presence of $\mathrm{ME}\left(1\right.$ at $\left.10 \mu \mathrm{g} \mathrm{mL} \mathrm{m}^{-1}\right)$, in relation with $100 \%$ hemolysis induced by water. A control test (only erythrocytes) in the absence of ME and AAPH was made (control). (B) Hemolysis inhibition by $\mathrm{ME}$ and ascorbic acid (AA, 0.5 at $15 \mu \mathrm{g} \mathrm{mL}^{-1}$ ) after $4 \mathrm{~h}$ of incubation, in relation with control assay (absence of antioxidant). Mean \pm standard deviation for assay made in triplicate from 3 extractions $(n=3)$.

AAPH decomposition in the presence of oxygen generates peroxyl radical causing oxidative damage in cell membranes. Erythrocytes are very susceptible to oxidative damage by the high content of polyunsaturated fatty acids in their membranes and high cell concentrations of oxygen and hemoglobin ${ }^{28}$. Thus, peroxyl radical, generated by the decomposition of AAPH, attacks cell membranes of erythrocytes induced by lipid peroxidation and protein conformational changes, leading to hemolysis ${ }^{8,40}$. Similarly, in the present study, it was observed effects of peroxyl radicals initiated by AAPH on human erythrocytes lyses. A lag phase in the progress curve of hemolysis during incubation with AAPH was observed, suggesting a complex mechanism in the oxidative damage process. Our findings indicated that the antihemolytic effect was more efficient by ME than by ascorbic acid. In addition, flavonoid compounds showed protective effect against hemolysis induced by AAPH in erythrocytes of rats ${ }^{41}$. The possible mechanisms of these protective effects of flavonoid-rich fractions may be through their radical scavenging, metal chelating and reducing power activities ${ }^{41}$.

\section{Conclusions}

The antioxidant action found in this study clearly demonstrates that ME is able to eliminate synthetic and naturally occurring free radicals, suggesting its potential to prevent oxidative damage in vivo as well as in foodstuffs. In fact, the ME exerted protective action on erythrocytes membrane lysis.

\section{Acknowledgments}

The authors thank Prof. Dr. Olga Maria M. de Faria-Oliveira for her collaboration in the standardization of the techniques employed in the present study.

\section{References}

[1] Chanda, S., Dave, R., In vitro models for antioxidant activity evaluation and some medicinal plants possessing antioxidant properties: An overview, Afr. J. Microbiol. Res. 3 (2009) 981-996.

[2] Fernandes, R. P. P., Trindade, M. A., Tonin, F. G., Lima, C. G., Pugine, S. M. P., Munekata, P. E. S., Lorenzo, J. M., De Melo, M. P., Evaluation of antioxidant capacity of 13 plant extracts by three different methods: cluster analyses applied for selection of the natural extracts with higher antioxidant capacity to replace synthetic antioxidant in lamb burgers, J. Food Sci. Technol. 53 (2016) 451-460. https://doi.org/10.1007/s13197-015-1994-x.

[3] Sentkowska, A., Biesaga, M., Pyrzynska, K., Polyphenolic Composition and Antioxidative Properties of Lemon Balm (Melissa officinalis L.) Extract Affected by Different Brewing Processes, Int. J. Food Prop. 18 (2015) 2009-2014. https://doi.org/10.1080/10942912.2014.960932. 
[4] Lin, J. T., Chen, Y. C., Lee, Y. C., Rolis Hou, C. W., Chen, F. L., Yang, D. J., Antioxidant, antiproliferative and cyclooxygenase-2 inhibitory activities of ethanolic extracts from lemon balm (Melissa officinalis L.) leaves, LWT-Food Sci. $\begin{array}{llll}\text { Technol. } & 49 & \text { (2012) } & \text { 1-7. }\end{array}$ https://doi.org/10.1016/j.lwt.2012.04.009.

[5] Zemmouri, H., Ammar, S., Boumendjel, A., Messarah, M., Feki, A. E., Bouaziz, M., Chemical composition and antioxidant activity of Borago officinalis L. leaf extract growing in Algeria, Arabian J. Chem. article in press (2014). https://doi.org/10.1016/j.arabjc.2014.11.059.

[6] Wojdylo, A., Oszmianski, J., Czemerys, R., Antioxidant activity and phenolic compounds in 32 selected herbs, Food Chem. 105 (2007) 940949.

https://doi.org/10.1016/j.foodchem.2007.04.038.

[7] Duda, S. C., Mărghitaş, L. A., Dezmirean, D., Duda, M., Mărgăoan, R., Bobiş, O., Changes in major bioactive compounds with antioxidant activity of Agastache foeniculum, Lavandula angustifolia, Melissa officinalis and Nepeta cataria: Effect of harvest time and plant species, Int. J. Food Prop. 77 (2015) 499-507. https://doi.org/10.1016/j.indcrop.2015.09.045.

[8] Vellosa, J. C. R., Regaini L. O., Khalil, N. M., Bolzani, V. S., Khalil O. K., Manente, F. A., Netto H. P., Faria-Oliveira O. M. M., Antioxidant and cytotoxic studies for kaempferol, quercetin and isoquercetin, Eclet. Quim. 36 (2011) 7-19. https://doi.org/10.1590/S0100-

46702011000200001.

[9] Halliwell, B., Gutteridge, J., Free Radicals in Biology and Medicine, New York: Oxford University Press Inc.; $2^{\text {nd }}$ ed.; 2007, ch 3.

[10] Conforti, F., Marrelli, M., Carmela, C., Menichini, F., Valentina, P., Uzunov, D., Statti, G. A., Duez, P., Menichini, F., Bioactive phytonutrients (omega fatty acids, tocopherols, polyphenols), in vitro inhibition of nitric oxide production and free radical scavenging activity of non-cultivated Mediterranean vegetables, Food $\begin{array}{llll}\text { Chem. } & 129 & \text { (2011) 1413-1419. }\end{array}$ https://doi.org/10.1016/j.foodchem.2011.05.085.
[11] Valko, M., Leibfritz, D., Moncol, J., Cronin, M. T. D., Mazur, M., Telser, J., Free radicals and antioxidants in normal physiological functions and human disease, Int. J. Biochem. Cell Biol. 39 (207) 44-84. https://doi.org/10.1016/j.biocel.2006.07.001.

[12] Prior, R. L., Wu, X., Schaich, K., Standardized methods for the determination of antioxidant capacity and phenolics in foods and dietary supplements, J. Agric. Food Chem. 53 (2005)

4290-4302. https://doi.org 10.1021/jf0502698.

[13] Carocho, M., Ferreira, I. C. F. R., A review on antioxidants, prooxidants and related controversy: Natural and synthetic compounds, screening and analysis methodologies and future perspectives, Food Chem. Toxicol. 51 (2013) 1525. https://doi.org/10.1016/j.fct.2012.09.

[14] Vargas, F. C., Arantes-Pereira, L., Costa, P. A., De Melo, M. P., Sobral, P. J. A., Rosemary and Pitanga Aqueous Leaf Extracts On Beef Patties Stability under Cold Storage, Braz. Arch. Biol. Technol. $\quad 59 \quad$ (2016) 1-10. https://doi.org/10.1590/1678-4324-2016160139.

[15] Floegel, A., Kim, D. O., Chung, S. J., Koo, S. I., Chun, O. K., Comparison of ABTS/DPPH assays to measure antioxidant capacity in popular antioxidant-rich US foods, J. Food Compos. Anal. $24 \quad$ (2011) 1043-1048. https://doi.org/10.1016/j.jfca.2011.01.008.

[16] López-Alarcón, C., Denicola, A., Evaluating the antioxidant capacity of natural products: $\mathrm{A}$ review on chemical and cellular-based assays, Anal. Chim. Acta 763 (2013) 1-10. https://doi.org/10.1016/j.aca.2012.11.051.

[17] Gião, M. S., Leitão, I., Pereira, A., Borges, A. B., Guedes, C. J., Fernandes, J. C., Belo, L., Santos-Silva, A., Hogg, T. A., Pintado, M. E., Malcata, F. X., Plant aqueous extracts: Antioxidant capacity via haemolysis and bacteriophage P22 protection. Food Control. 21 (2010) 633-638. https://doi.org/10.1016/j.foodcont.2009.08.014.

[18] Virot, M., Tomao, V., Colnagui, G., Visinoni, F., Chemat, F., New microwave-integrated Soxhlet extraction. An advantageous tool for the 
extraction of lipids from food products, J. Chromatogr. A. 1174 (2007) 138-144. https://doi.org/10.1016/j.chroma.2007.09.067.

[19] Singleton, V. L., Rossi Junior, J. A., Colorimetry of total phenolics with phosphomolybdic-phosphotungstic acid reagents, Am. J. Enol. Vitic. 16 (1965) 144-158.

[20] Miliauskas, G., Venskutonis, P. R., van Beek, T. A., Screening of radical scavenging activity of some medicinal and aromatic plant extracts, Food Chem. $\quad 85 \quad$ (2004) 231-237. https://doi.org:10.1016/j.foodchem.2003.05.007.

[21] Benzie, I. F. F., Strain, J. J., The Ferric Reducing Ability of Plasma (FRAP) as a Measure of "Antioxidant Power": The FRAP Assay, Anal. Biochem. $239 \quad$ (1996) 70-76. https://doi.org/10.1006/abio.1996.0292.

[22] Brand-Williams, W., Cuvelier, M. E., Berset, C., Use of a free radical method to evaluate antioxidant activity, LWT-Food Sci. Technol. 28 (1995) 25-30. https://doi.org/10.1016/S00236438(95)80008-5.

[23] Valentão, P., Fernandes, E., Carvalho, F., Andrade, P. B., Seabra, R. M., Bastos, M. L., Antioxidant activity of Centaurium erythraea infusion evidenced by its superoxide radical scavenging and xanthine oxidase inhibitory activity, J. Agric. Food Chem. 49 (2001) 34763479. https://doi.org/10.1021/jf001145s.

[24] Orak, H. H., Isbilir, S. S., Yagar, H., Determination of antioxidant properties of lyophilized olive leaf water extracts obtained from 21 different cultivars, Food Sci. Biotechnol. 21 (2012) 1065-1074. https://doi.org/10.1007/s10068-012-0138-6.

[25] Marcocci, L., Maguire, J. J., Droy-Lefaix, M. T., Packer, L., The nitric oxide-scavenging properties of ginkgo biloba extract EGb 761, Biochem. Biophys. Res. Commun. 201 (1994) 748-755. https://doi.org/10.1006/bbrc.1994.1764.

[26] Pooja, P. S., Samanta, K. C., Garg, V., Evaluation of nitric oxide and hydrogen peroxide scavenging activity dalbergia sissoo roots, $\begin{array}{llll}\text { Pharmacophore } & 1 & \text { (2010) 77-88. }\end{array}$ http://www.pharmacophorejournal.com.
[27] Simão, A. N. C., Suzukawa, A. A., Casado, M. F., Oliveira, R. D., Guarnier, F. A., Cecchini, R., Genistein abrogates pre-hemolytic and oxidative stress damage induced by 2,2'-Azobis (Amidinopropane), Life Sci. 78 (2006) 12021210. https://doi.org/10.1016/j.lfs.2005.06.047.

[28] Yang, H. L., Chen, S. C., Chang, N. W., Chang, J. M., Lee, M. L., Tsai, P. C., Fu, H. H., Kao, W. W., Chiang, H. C., Wang, H. H., Hseu, Y. C., Protection from oxidative damage using Bidens pilosa extracts in normal human erythrocytes, Food Chem. Toxicol. 44 (2006) 1513-1521.

https://doi.org/10.1016/j.fct.2006.04.006.

[29] Rababah, T. M., Al, U., Datt, M., Alhamad, M., Al-Mahasneh, M., Ereifej, K., Andrade, J., Altarifi, B., Almajwal, A., Yang, W., Effects of drying process on total phenolics, antioxidant activity and flavonoid contents of common mediterranean herbs, Int. J. Agric. \& Biol. Eng. 8 (2015) $145-150$ https://doi.org/10.3965/j.ijabe.20150802.1496.

[30] Dudek, G., Strzelewicz, A., Krasowska, M., Rybak, A., Turczyn, R., A spectrophotometric method for plant pigments determination and herbs classification, Chem. Pap. 68 (2014) 579583. https://doi.org/10.2478/s11696-013-0502-X.

[31] Oktay, M., Gülçin, I., Küfreviogle, Ö. I., Determination of in vitro antioxidant activity of fennel (Foeniculum vulgare) seed extracts, LWTFood Sci. Technol. 36 (2003) 263-271. https://doi.org/10.1016/S0023-6438(02)00226-8.

[32] Halliwell, B., Gutteridge, J. M. C., Cross, C. E., Free radicals, antioxidants, and human disease: Where are we now? J. Lab. Clin. Med. 119 (1992) 598-620. PMID: 1593209.

[33] López, V., Akerreta, S., Casanova, E., García-Mina, J. M., Cavero, R. Y., Calvo, M. I., In Vitro Antioxidant and Anti-rhizopus Activities of Lamiaceae Herbal Extracts, Plant. Foods Hum. Nutr. $\quad 62 \quad$ (2007) 151-155. https://doi.org/10.1007/s11130-007-0056-6.

[34] Kamdem, J. P., Adeniran, A., Boligon, A. A., Klimaczewski, C. V., Elekofehinti, O. O., Hassan, W., Ibrahim, M., Waczuk, E. P., Meinerz, D. F., 
Athayde, M. L., Antioxidant activity, genotoxicity and cytotoxicity evaluation of lemon balm (Melissa officinalis L.) ethanolic extract: Its potential role in neuroprotection, Ind. Crops. Prod. 51 2613) 26-34. https://doi.org/10.1016/j.indcrop.2013.08.056.

[35] Skotti, E., Anastasaki, E., Kanellou, G., Polissiou, M., Tarantilis, P. A., Total phenolic content, antioxidant activity and toxicity of aqueous extracts from selected Greek medicinal and aromatic plants, Ind. Crops. Prod. 53 (2014) 46-54.

https://doi.org/10.1016/j.indcrop.2013.12.013.

[36] Ebrahimzadeh, M. A., Nabavi, S. F., Nabavi, S. M., Pourmorad, F., Nitric oxide radical scavenging potential of some Elburz medicinal plants, Afr. J. Biotechnol. 9 (2010) 5212-5217. https://doi.org/10.5897/AJB10.101.

[37] Law, A., Gauthier, S., Quirion, R., Say NO to Alzheimer's disease: the putative links between nitric oxide and dementia of the Alzheimer's type, Brain Res. Brain Res. Rev. 35 (2001) 73-96. https://doi.org/10.1016/S0165-0173(00)00051-5.

[38] Govindan, P., Muthukrishnan, S., Evaluation of total phenolic content and free radical scavenging activity of Boerhavia erecta, J. Acute. Med. 3 (2013) 103-109. https://doi.org/10.1016/j.jacme.2013.06.003.

[39] Manoharan, S., Guillemin, G. J., Abiramasundari, R. S., Essa, M. M., Akbar, M., Akbar, M. D., The Role of Reactive Oxygen Species in the Pathogenesis of Alzheimer's Disease, Parkinson's Disease, and Huntington's Disease: A Mini Review, Oxid. Med. Cell Longev. $2016 \quad$ (2016) 1-15. https://doi.org/10.1155/2016/8590578.

[40] Zou, C. G., Agar, N. S., Jones, G. L., Oxidative insult to human red blood cells induced by free radical initiator AAPH and its inhibition by a commercial antioxidant mixture, Life Sci. 69(2001) 75-86. https//doi.org/10.1016/S00243205(01)01112-2.

[41] Alinezhad, H., Zare, M., Nabavi, S. F., Naqinezhad, A., Nabavi, S. M., Antioxidant, antihemolytic, and inhibitory activities of endemic Primula heterochroma against $\mathrm{Fe} 2+$-induced lipid peroxidation and oxidative stress in rat brain in vitro, Pharm. Biol. 50 (2012) 1391-1396. https://doi.org/10.3109/13880209.2012.676050. 